\title{
Conversion of Gasoline Engine
}

\author{
Anita Soni ${ }^{1}$ Prof. P.G.Khot ${ }^{2}$ \\ A.P - T.I.T College Bhopal, H.O.D. Statistics Dept. Nagpur University, Maharashtra,
}

\begin{abstract}
Oil security for a nation, that is, aspiring to be an economic power, is very vital. Equity oil abroad may lessen our dependence on a few suppliers and increase our inter-dependence on a global basis. Considering the oil demand scenario vis-à-vis domestic production level on the one hand and low crude oil reserve replenishment trend and high risk of domestic exploration on the other, a major focus of NOCs/Indian private companies would be to venture abroad to access exploration blocks and producing properties for equity oil. If we mix Cashew nut shell oil in fuel, then we are able to save our natural resources of fuel and atmosphere.
\end{abstract}

\section{INTRODUCTION}

Modern energy enriches our life. Now consider the 7 billion people on earth who use energy each day to make their own lives richer, more productive, safer and healthier. Then you will recognize what is perhaps the biggest driver of energy demand: the human desire to sustain and improve the well-being of ourselves, our families and our communities. Through 2040, population and economic growth will drive demand higher, but the world will use energy more efficiently and shift toward lower-carbon fuels.

From cars to cell phones, pharmaceuticals to plastics and air conditioning to water heating, energy is part of people's lives more than ever before. But energy's benefits extend far beyond what people use individually at home, at work and on the road. A range of essential activities - including agriculture, computing, manufacturing, construction, and health and social services - depends on access to modern energy. In addition, many familiar elements of modern life would not exist without the plastics, chemicals and fertilizers made from oil and natural gas. Cap rocks are rocks that are impervious and they resist the flow of fluids such as water, petroleum and gas and trap these fluids in rocks below. Reservoir rocks act as a storage medium for petroleum. They have sufficient cracks and fissures to allow the petroleum seeping up to the surface and escaping. Source rocks are those in which petroleum is generated. The dominant classical view is that source rocks must have layers containing the bodies of deal plants and animals and that these gradually changes into petroleum.

By distillation from Crude Oil we get petrol, kerosene, diesel etc. Petrol was known as Black Gold and was a natural resource. Demand of petrol is on hike; it directly affects its price, and in turn affects the burden on the pockets of vehicle owners. In all over the world many scientists are working on this above topic, but till now nobody has been successful. Expert's decisions are not possible to implement directly because the environmental condition of India is different from developed countries. Presently, about $40 \%$ of the total consumption of petrol production of the country is used in road transport sector; while the balance $60 \%$ is used in industries including power generation, domestic and for other miscellaneous purposes. Petrol consumption in any developed city is 2.25 to 3 Lakhs of liter /day \& near about total 90 to 100 petrol pumps.

Related to the above matter I have presented paper are

- Alternative Fuels (IJET) (ISSN NO. - 0975-8364)

- Gasoline - I (IJATER) (ISSN NO. - 2250 - 3536)

- $\quad$ Alternative Fuels - II (IJET) (ISSN NO. - 0975-8364)

- $\quad$ Gasoline - II (IJATER) (ISSN NO. - 2250- 3536)

\section{The starting performance of blended fuel}

The starting performance of gasoline depends on its forerunning point and the temperature at which $10 \%$ distillate is released. When gasoline is mixed with alcohol, the starting performance of the blend fuel mainly depends on the performance of alcohol vaporization. The latent heat of alcohol is about $216 \mathrm{Kcal} / \mathrm{Kg}$, while that of gasoline is $80 \mathrm{Kcal} / \mathrm{kg}$. Besides, the latent heat of alcohol also increases with the proportion of water in alcohol. This makes alcohol absorb much more heat than gasoline does during vaporization, thus reducing the admission temperature in engine, and causing difficulty in starting the engine. The specific heat of alcohol is $0.65 \mathrm{Kcal} / \mathrm{kg}^{\circ} \mathrm{C}$ at $20^{\circ} \mathrm{C}$, which is higher than that of gasoline $\left(0.58 \mathrm{Kcal} / \mathrm{Kg}^{\circ} \mathrm{C}\right)$. It increases too with the proportion of water in alcohol, leading to low temperature at the end of compression stroke and making it difficult for the engine to start. In addition, the low boiling point of alcohol as well as arise in temperature in the engine may cause an air plug, and make the engine difficult to start. 


\section{The octane number of blend fuel}

Alcohol has a high octane number, RON being 110, and MON 90. Its antiknock performance is good. If alcohol contains a certain amount of water, it is favorable to improve its antiknock performance; hence the enhancement of the compression ratio of the engine occurs when the blended fuel is burned. Meanwhile, an alcohol blend requires no or reduced additive of antiknock substance, which may reduce air pollution caused by lead $(\mathrm{pb})$. But the effect on increasing of the octane number of blended fuel is not the same when gasoline is mixed with different kinds of alcohol, as is shown in Table 1.4., show that the change in octane number of blended fuel is in nonlinear correlation with the proportion of alcohol added. A 5\%-20\% alcohol blend has a higher mixed octane number. This means that the effect on raising the octane number of blend fuel is more notable. In addition, the lower the octane number of base gasoline is, the more notable the effect on raising the octane number of blended fuel.

Schematic Arrangement of fuel supply

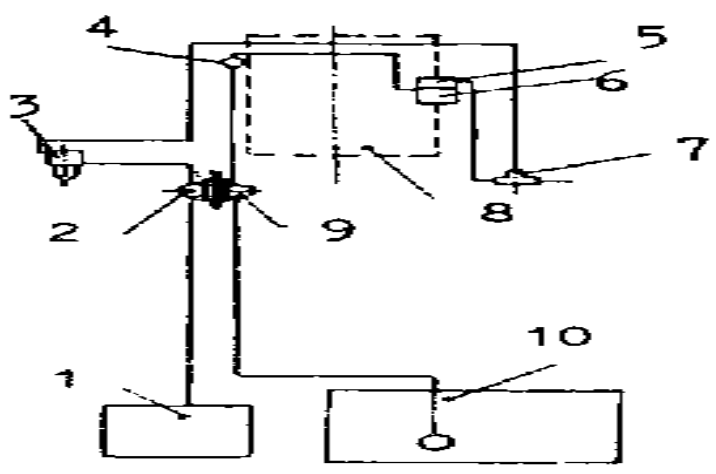

Fig- 1

Table 1 Octane number (Motor method)

\begin{tabular}{|c|c|c|c|c|}
\hline $\begin{array}{l}\text { Ethanol } \\
\text { in the } \\
\text { mixture } \\
(\%)\end{array}$ & \multicolumn{2}{|l|}{ Octane (M) } & \multicolumn{2}{l}{ Mixed Octane (M) } \\
\hline & A & B & a & b \\
\hline 0 & 72.5 & 60.6 & - & - \\
\hline 5 & 74.8 & - & 118.5 & - \\
\hline 10 & 76.6 & - & 113.5 & - \\
\hline 15 & 78.5 & 73.4 & 112.5 & 143.00 \\
\hline 20 & 80.3 & 76.7 & 111.5 & 141.10 \\
\hline 25 & 81.4 & - & 108.1 & - \\
\hline 55 & - & 87.4 & - & 109.33 \\
\hline 60 & - & 87.7 & - & 105.77 \\
\hline 70 & - & 88.6 & - & 100.60 \\
\hline 80 & - & 89.7 & - & 96.98 \\
\hline 90 & - & 89.9 & - & 93.16 \\
\hline 100 & 90.0 & 91.6 & 90.0 & 91.60 \\
\hline
\end{tabular}

a - Data in this column are from literature (2).

$\mathrm{b}$ - Data in this column are collected from laboratory.

1 - Alcohol tank, 2 - Alcohol filter, 3 - Alcohol pump, 4 - Gasoline pump, 5 - Alcohol float chamber,

6 - Carburetor, 7 - T-tube, 8 - Engine, 9 - Gasoline filter, 10 - Gasoline tank

Based on the foregoing conclusion, selecting 15\%-20\% of low proof alcohol blend has the advantage of putting the alcohol's high antiknock performance into full play. Meanwhile if a low octane gasoline is used as the base for the blend, without adding any antiknock fluid, not only can the pollution by lead be reduced, but also the cost of fuel is decreased, thus making the use of mixed fuel on gasoline engine.

Conversion methods and materials of gasoline engine

Firstly, the conversion of the engine should meet the needs of the blended fuel with 15\%-20\% alcohol of 170-180 proof. Moreover, the conversion and operation of the engine should be convenient. And the performance of original engine should not be changed too much in some circumstances; the engine may be 
switched over to gasoline alone. During operation, the ratio of alcohol to gasoline should not fluctuate more than $5 \%$ after some possible conversion methods were analyzed. The method using two float chambers of one carburetor was adopted. During operation, two fuel supply systems fed alcohol and gasoline to one carburetor through two float chambers, respectively. According to the different ways in which alcohol and gasoline were mixed, there were approaches. In the first approach, the alcohol and gasoline were mixed inside the main metering jet tube of the carburetor; in the second approach, the alcohol from the alcohol float chamber was conducted to a new main metering jet tube opposite to the main metering jet tube of gasoline.

\section{Structure of the carburetor}

1 - Alcohol inlet (second approach)

2 - Carburetor

3 - Alcohol flood chamber

4 - Alcohol outlet

5 - Alcohol pipe

6 - Alcohol inlet (first approach)

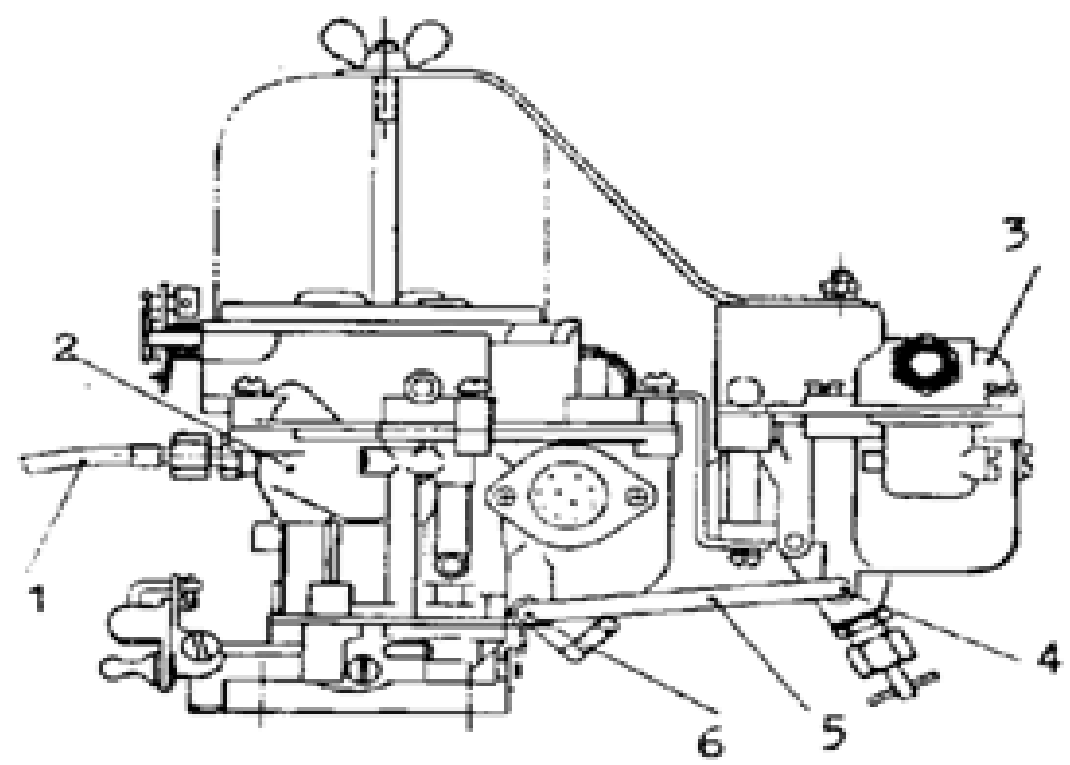

Fig -1.2

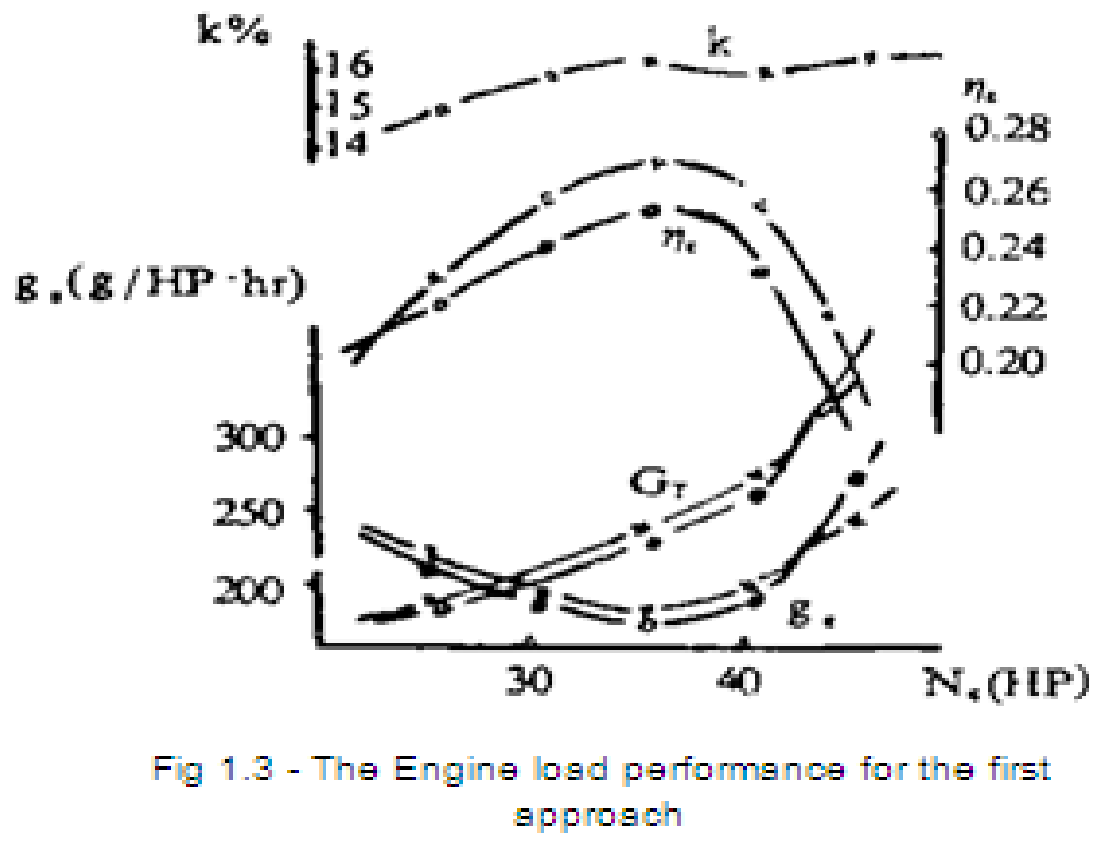




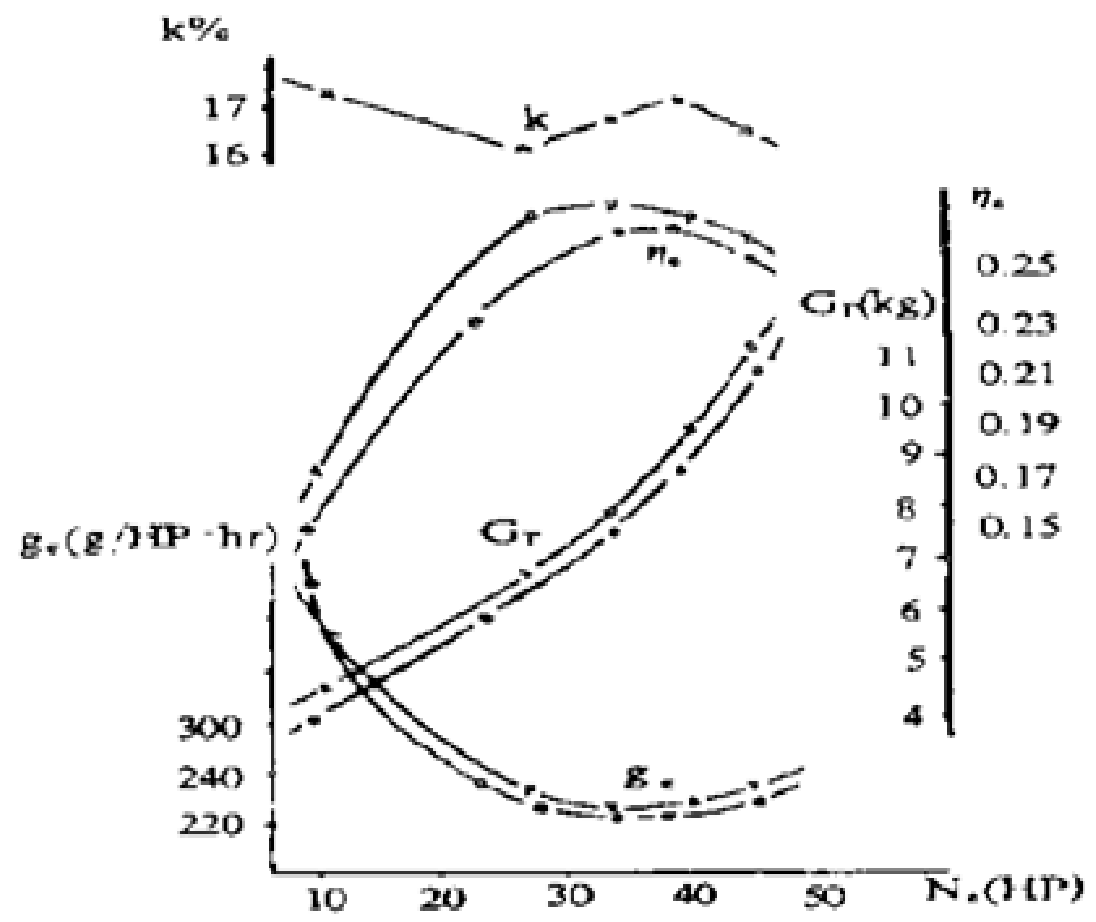

Figs 1.4 - The Engine load performance for the second approach

After conversion, several contrast tests between the original engine and the converted engine were carried out in order to investigate the engine characteristics, including velocity performance and load performance, exhaust gases, zero load performance, vehicle's travelling performance, and corrosion and wearing.

\section{TEST RESULTS AND DISCUSSIONS}

\section{A. Stability of the ratio of alcohol to gasoline}

From the velocity performances of the engine, it can be seen that the absolute value of ratio of alcohol to gasoline fluctuated from $1 \%$ to $2 \%$ under very wide speed range of the engine for both approaches. In addition, from the load performances of engine, it can be seen that the absolute value of the ratio of alcohol to gasoline varies at the range of 1.2\%-2.5\% from a small percentage of an open throttle to the complete opening of the throttle for both float chamber methods. Therefore, it shows that the ratio of alcohol to gasoline is basically stable at different velocities and loads.

\section{b. Power and specific fuel consumption}

The velocity performances of engine, it can be seen that the power of engine operating on blend fuel is about the same as that of the engine running on gasoline alone. Although the caloric value of alcohol is lower than that of gasoline, the air-fuel ratio of alcohol is lower than that of gasoline. So the caloric values of combustible gas in the two cases are about the same. Test showed that the engine using blended fuel, which is made by mixing gasoline with 15\%-20\%. Load performances of the engine, it can be seen that the engine's specific fuel consumption when using blended fuel is higher than that when operating on gasoline. This happens because the caloric value of blended fuel is lower than that of gasoline. However, due to the fact that blend fuel has a higher octane number, the combustion properties are improved when blended fuel is used. The effective efficiency of blended fuel is higher than that of gasoline under all RPM and load conditions.

\section{B. Start performance:}

Table -2 Shows Vacuum levels of idle port and main discharge nozzle.

\begin{tabular}{|c|c|c|c|c|}
\hline Throttle & \multicolumn{2}{|c|}{$\mathbf{1 0 0 \%}$ open of choke } & \multicolumn{2}{c|}{$\mathbf{1 0 0 \%}$ close of choke } \\
\hline open (angle) & Idle port nozzle & Main discharge & Idle port nozzle & Main discharge \\
\hline $11^{\circ}$ & 230 & 1 & 240 & 80 \\
\hline $22.5^{\circ}$ & 215 & 6 & 225 & 105 \\
\hline
\end{tabular}

Note: unit, $\mathrm{mm} \mathrm{H}_{2} \mathrm{O}$ 


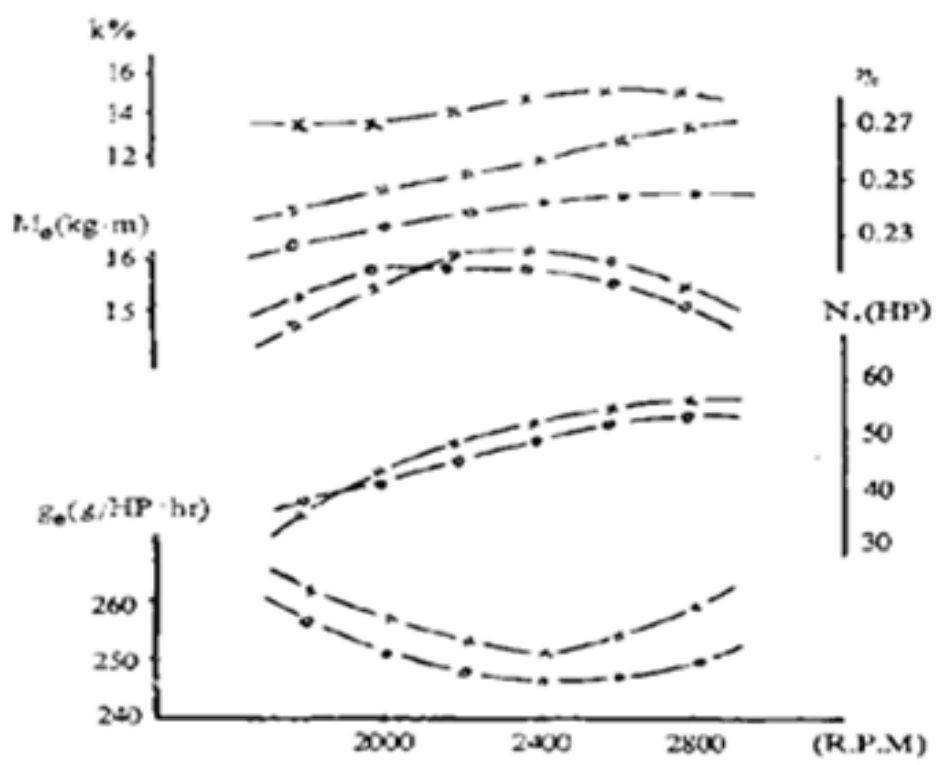

Fig 1.5 - The engine load performance for the second approach (2000 rpm)

In choosing the conversion methods, the start problem of the engine has already been considered when engine is started; the throttle of the carburetor is open at a small percentage. Above Table shows: The vacuum level of idle port is much higher than that of main discharge nozzle during the start. Therefore, when engine is started, the fuel supply depends on the idle port. At this time, the main discharge nozzle nearly stops supplying fuel. This means that it is the idling system that affected the start performance of the engine.

The velocity performance of the converted engine at idle condition was tested. From Fig. 1.6, it is known that the ratio of alcohol to gasoline fluctuates between 3\% and 7.5\% at 800-2000 RPM. The engine burns nearly gasoline alone under $800 \mathrm{RPM}$. Above results indicate that the fuel injected from idle port is nearly gasoline alone at a low speed starting condition. Hence, the alcohol does not have an effect on the star performance of the engine.

\section{Vehicle's travelling performance}

The acceleration of engine and fuel consumption per unit distance at a constant speed. In addition, 70 gasolines alone were used in the same vehicle to contrast with the burning blended fuel. The ignition-delay periods were adjusted to an optical value in above two cases. The data in acceleration test were shown in Table 5.6., it can be seen that the acceleration time of the vehicle running on blended fuel is 2.94 seconds less than that of operating on gasoline. The acceleration of the former is $0.04 \mathrm{~m} / \mathrm{s}^{2}$ faster than that of the latter. The fuel consumption per unit acceleration of vehicle on the blended fuel is $174.68 \mathrm{~g} / \mathrm{ms}^{2}$ and on gasoline is $174.83 \mathrm{~g} / \mathrm{ms}^{2}$. The two are nearly the same.

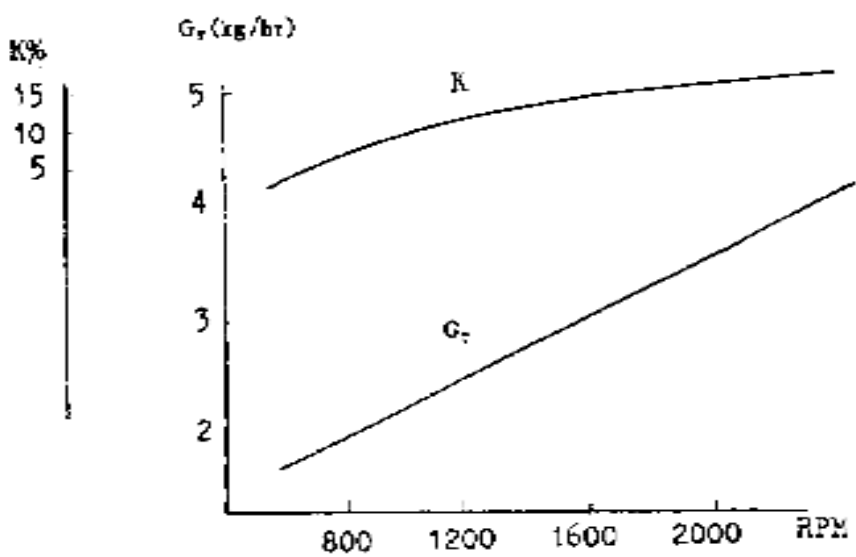

Fig.1.6 The velocity performance of the converted engine at idle condition 
Table 3 Acceleration properties

\begin{tabular}{|c|c|c|c|c|c|c|c|c|}
\hline \multicolumn{2}{|c|}{ Velocity (km/h) } & \multicolumn{2}{|c|}{ Time (e) } & \multicolumn{2}{c|}{ Acceleration $\left(\mathrm{m} / \mathrm{s}^{2}\right)$} & \multicolumn{3}{c|}{ Fuel consumption (g) } \\
\hline Begin & End & B & G & B & G & B & G & R (\%) \\
\hline \multirow{3}{*}{30} & \multirow{3}{*}{70} & 26.4 & 29.1 & 0.42 & 0.38 & 71.67 & 63.13 & 16.3 \\
\cline { 3 - 9 } & 27.1 & 31.7 & 0.41 & 0.35 & 69.21 & 66.72 & 17.4 \\
\cline { 3 - 9 } & 29.3 & 30.9 & 0.88 & 0.36 & 70.71 & 67.00 & 18.0 \\
\cline { 3 - 9 } & 29.4 & 30.6 & 0.38 & 0.36 & 73.93 & 63.83 & 16.7 \\
\cline { 3 - 9 } & 24.2 & 28.8 & 0.46 & 0.39 & 72.56 & 62.78 & 16.7 \\
\hline \multicolumn{2}{|l|}{ Average } & 27.28 & 30.22 & 0.41 & 0.37 & 71.62 & 64.69 & 16.6 \\
\hline
\end{tabular}

Note: B: Blend fuel; G: Gasoline; R: Ratio of ethanol to gasoline in the blend fuel

The data in the Table 4 and Table 5 indicate that the average fuel consumption per $100 \mathrm{~km}$ of the vehicle running on blend fuel is $0.62 \mathrm{~kg}$ higher than that of running on gasoline alone. The difference is $8.16 \%$. The reason is that the heat value of alcohol is only $2 / 3$ of the gasoline heat value. In addition, the heat consumption ratio of vehicle running on blend fuel is $3.3 \mathrm{kcal} / \mathrm{km}$ higher than that of running on gasoline. The difference is only $0.45 \%$. Moreover, the ratio of alcohol to gasoline is ranged within $18.2 \%$ to $20 \%$ at different speeds, which shows that the ratio is stable.

Table 4 Fuel consumption of blend fuel at a constant speed

\begin{tabular}{|c|c|c|c|c|c|c|c|}
\hline & \multirow[t]{2}{*}{ Time } & \multirow[t]{2}{*}{$\begin{array}{l}\text { Velocity } \\
(\mathrm{km} / \mathrm{hr})\end{array}$} & \multicolumn{2}{|c|}{ Fuel consumption $(\mathrm{g})$} & \multicolumn{2}{|c|}{$\begin{array}{l}\text { Fuel Consumption rate } \\
(\mathrm{kg} / 100 \mathrm{~km})\end{array}$} & \multirow{2}{*}{$\begin{array}{l}\text { Heat con } \\
\text { ratio }(106 \\
\mathrm{cal} / 100 \mathrm{~km})\end{array}$} \\
\hline & & & Alcohol & Gasoline & Alcohol & Gasoline & \\
\hline 1. & 120.5 & 29.87 & 15.58 & 60.40 & 1.56 & 6.04 & - \\
\hline 2 & 121 & 29.75 & 16.81 & 60.94 & 1.68 & 6.09 & 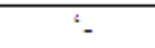 \\
\hline 3 & 120.8 & 29.81 & 16.20 & 60.7 & 1.62 & 6.07 & 73.46 \\
\hline 4 & 89.2 & 40.35 & 14.8 & 57.7 & 1.48 & 5.77 & - \\
\hline 5 & 90.1 & 39.96 & 15.6 & 60.6 & 1.56 & 6.06 & '- \\
\hline 6 & 99.65 & 40.16 & 15.7 & 59.1 & 1.52 & 5.91 & 71.18 \\
\hline 7 & 72.2 & 49.86 & 13.9 & 57.9 & 1.39 & 5.79 & 5 \\
\hline 8 & 71.8 & 50.16 & 15.6 & 58.8 & 1.56 & 5.88 & 5 \\
\hline 9 & 72 & 50 & 14.8 & 58.4 & 1.48 & 5.84 & 70.2 \\
\hline 10 & 59.4 & 60.60 & 14.8 & 59.4 & 1.48 & 5.94 & 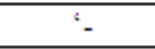 \\
\hline 11 & 58.9 & 61.12 & 15.2 & 62.2 & 1.52 & 6.22 & 72.84 \\
\hline 12 & 59.15 & 60.86 & 15.0 & 60.8 & 1.50 & 6.08 & - \\
\hline 13 & 51.5 & 69.90 & 14.4 & 64.2 & 1.44 & 6.42 & 5 \\
\hline 14 & 51.2 & 70.31 & 15.2 & 66.0 & 1.52 & 6.60 & 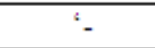 \\
\hline Average & 51.35 & 70.11 & 14.8 & 65.1 & 1.48 & 6.51 & 77.24 \\
\hline
\end{tabular}

Table 5 Fuel consumption of gasoline at a constant speed

\begin{tabular}{|c|c|c|c|c|c|}
\hline S.no & Time & Velocity & $\begin{array}{c}\text { Fuel } \\
\text { Con. }(\mathrm{g})\end{array}$ & $\begin{array}{c}\text { Fuel Con. } \\
\text { Rate }(\mathrm{kg} / 100 \mathrm{~km})\end{array}$ & $\begin{array}{l}\text { Heat con. Rate }\left(10^{6}\right. \\
\text { cal/100km) }\end{array}$ \\
\hline 1 & 120.9 & 29.78 & 69.3 & 6.93 & - \\
\hline 2 & 119.6 & 30.1 & 71.2 & 7.12 & 3 \\
\hline 3 & 120.25 & 29.94 & 70.2 & 7.02 & 73.71 \\
\hline 4 & 89.6 & 40.18 & 67.6 & 6.76 & 3 \\
\hline 5 & 89.7 & 40.13 & 69.4 & 6.94 & - \\
\hline 6 & 89.65 & 40.16 & 68.5 & 6.85 & 71.93 \\
\hline 7 & 72.1 & 49.93 & 66.4 & 6.64 & - \\
\hline 8 & 72.3 & 49.79 & 65.9 & 6.59 & - \\
\hline 9 & 72.2 & 49.86 & 66.2 & 6.62 & 69.51 \\
\hline 10 & 59.6 & 60.4 & 68.2 & 6.82 & - \\
\hline 11 & 59.1 & 60.91 & 69.1 & 6.91 & - \\
\hline 12 & 59.35 & 60.66 & 68.6 & 6.86 & 72.03 \\
\hline 13 & 51.2 & 70.31 & 74.8 & 7.48 & - \\
\hline 14 & 51.6 & 69.77 & 76.4 & 7.64 & - \\
\hline Average & 51.4 & 70.04 & 75.6 & 7.56 & 79.38 \\
\hline
\end{tabular}




\section{The effect of blended fuel on corrosion and wearing down of the engine}

During the operation of the engine, the metal particles from the machine elements, due to the wearing down of the engine, entered lubricating oil at a suspension state. According to the theory analysis, the amount of metal particles suspended in the lubricating oil is related to the wearing down level of machine elements. Therefore, the wearing down of the engine can be estimated by measuring the iron content in the oil residue in engine. The machine elements which are easy to wear down are in the cylinder wall and piston ring. In our study, the wearing down of engine operating on blended fuel was estimated by measuring the iron content in oil residue in the engine after a car had traveled a certain mileage. The Fig. $(1.3,1.4 \& 1.5)$ was then compared with that in the engine burning gasoline. At the same time, the kinematic viscosity and the acid value of oil residue in the two cases were also tested in order to determine the corrosion of engine.

The Table-6, Table-7 and Table- 8 show the iron content in residue oil, kinematic viscosity and acid value, respectively. The results indicate that the iron content in the oil residue of a car using blended fuel was lower than that of car using gasoline. Furthermore, the kinematic viscosity and the acid value of oil residue in the two cases were nearly the same, suggesting that alcohol had produced no more adverse effect on diluting and acidifying the oil than gasoline. Besides, the maximum wearing down amounts of the engine cylinder burning blended fuels were $0.05 \mathrm{~mm}$ and $0.07 \mathrm{~mm}$ in within the diameter's direction after $25000 \mathrm{~km}$ and $51000 \mathrm{~km}$, were travelled respectively. The average maximum wearing down amount of engine cylinder in the diameter's direction was $0.014 \mathrm{~mm}$ which was lower than a typical wearing down amount. For example, the average maximum wearing amount per $10000 \mathrm{~km}$ of 492 QA engine burning gasoline is $0.0296 \mathrm{~mm}$ which is measured by a vehicle maintenance factory. All above results suggest that the blended fuel with $15 \%$ - $20 \%$ alcohol of 170 180 proof has no apparent effect on corrosion and wearing of the engine.

Table- 6 Iron content in residue o1

\begin{tabular}{|c|c|c|c|c|c|c|}
\hline \multirow{2}{*}{ S.no } & \multicolumn{2}{|c|}{ Distance $(\mathrm{Km})$} & \multicolumn{2}{c|}{ Iron centre it using blend fuel } & \multicolumn{2}{c|}{ Iron content using gasoline } \\
\cline { 2 - 7 } & Blend Fuel & Gasoline & Total (ppm) & Ppm/1000km & Total (ppm) & Ppm/1000km \\
\hline 1 & 4400 & 7700 & 58 & 13.18 & 223 & 28.96 \\
\hline 2 & 4400 & 4300 & 55 & 12.50 & 215 & 50.00 \\
\hline 3 & 5000 & 4700 & 35 & 7.00 & 115 & 24.47 \\
\hline 4 & 4600 & 4100 & 122 & 26.52 & 169 & 41.20 \\
\hline 5 & 4600 & 4600 & 224 & 48.70 & 143 & 31.09 \\
\hline 6 & 4300 & 5300 & 190 & 44.19 & 129 & 24.34 \\
\hline 7 & 4500 & - & 121 & 26.89 & & \\
\hline 8 & 4700 & - & 125 & 26.60 & & \\
\hline Average & & & 116.25 & 25.70 & 165.67 & 33.35 \\
\hline
\end{tabular}

Table-7 Kinematic viscosity of lubricating oil

\begin{tabular}{|c|c|c|c|}
\hline \multicolumn{2}{|l|}{ Distance (km) } & \multicolumn{2}{l|}{$\begin{array}{l}\text { Kinematic viscosity of } \\
\left(40^{\circ} \mathrm{c}, 10^{-6} \mathrm{~m} / \mathrm{s}\right) \\
\text { lubricating oil }\end{array}$} \\
\cline { 3 - 4 } & $\begin{array}{c}\text { Using blend } \\
\text { fuel }\end{array}$ & $\begin{array}{c}\text { Using } \\
\text { gasoline }\end{array}$ \\
\hline 1 & 4600 & 95.7 & - \\
\hline 2 & 4600 & 109 & - \\
\hline 3 & 4300 & 92.39 & - \\
\hline 4 & 4300 & - & 102.7 \\
\hline 5 & 4700 & - & 89.6 \\
\hline 6 & 4100 & - & 90.73 \\
\hline Average & - & 99.03 & 94.34 \\
\hline
\end{tabular}

Table- 8 Acid value of residue oil

\begin{tabular}{|c|l|c|c|}
\hline \multicolumn{2}{|c|}{ Distance $(\mathrm{km})$} & \multicolumn{2}{c|}{ Acid value $(\mathrm{mg} \mathrm{KOH} / \mathrm{g})$} \\
\cline { 3 - 4 } \multicolumn{2}{|c|}{} & Using blend fuel & Using gasoline \\
\hline 1 & 4600 & 0.50 & - \\
\hline 2 & 4600 & 0.69 & - \\
\hline 3 & 4300 & 0.51 & - \\
\hline 4 & 4300 & - & 0.41 \\
\hline 5 & 4700 & - & 0.69 \\
\hline 6 & 4100 & - & 0.60 \\
\hline Average & - & 0.57 & 0.57 \\
\hline
\end{tabular}




\section{E. The effect of blended fuel on the exhaust value}

Generally speaking, exhaust gases of engine at idling condition can be measured as sample gases. However, the converted engine supplies nearly no alcohol at a very low speed. Hence, the exhaust gases were measured at 550 RPM. Both HC and CO content were measured. When the engine burns blended fuel, the HC and $\mathrm{CO}$ content are 500 PPM and 6.8\%, respectively. Whereas the engine burning gasoline alone exhausts 500 PPM HC and $6.8 \% \mathrm{CO}$.

The test data indicated that the exhaust value of engine operating on blend fuel is lower than that engine using gasoline. Cashew nut seeds oil, which is renewable easily replace furnace oil and LDO for most of the applications and save valuable foreign exchange by using waste product of cashew nut industry. Pure fuel polluted atmosphere more in Comparsion with mixed fuel. [18-20]

Conclusion Mixing gasoline (15\%-20\% alcohol) and cashew nut shell oil, with of $170-180$ proofs is a suitable choice for popularizing the use of blended fuel in the gasoline engine.

Burning a mixture of lead - free low - octane gasoline and low - proof alcohol can not only make the best use of high -octane value of alcohol but also reduce fuel cost.

No appreciable corrosion and unnatural wearing down in the main engine parts were observed.

When a gasoline engine is converted to alcohol / gasoline blended fuel by mixing it with cashew nut shell oil, it is crucial to maintain the stability of ratio between alcohol and gasoline during the operation of the engine. The conversions of the two approaches are simple. It is easy to control the engine. The cost of the conversion is low. And the engine performance is satisfactory and stable. At the same time, the converted engine can be switched over to gasoline alone when there is no alcohol available.

\section{REFERENCES}

[1]. LATEST NEWS - Petroleum -India to introduce 10\% ethanol blended petrol The National Ethanol Vehicle Coalition

[2]. http://www.eere.energy.gov/cleancities/progs/afdc/search_type.cgi?1|E85_GSLN http://www.autoauctions.gsa.go.

[3]. Brown J. A. and Manly, B.F.J. Statistical Workshop Notes. 2001. Science and Research Internal Report 187. Department of Conservation, Wellington. Industrial Engineering and Management (Journal).

[4]. Materials Management Journal of India (Journal). Ross, M. 1997. Fuel Efficiency and the Physics of Automobiles. Contemporary Physics, Vol. 38, No. 6, pp. 381-394.

[5]. Schuring, D. J. 1980. The Rolling Loss of Pneumatic Tires. Rubber Chemistry and Technology, Vol. 53, No. 3, pp. 600-727.

[6]. Schuring, D. J. 1994. Effects of Tire Rolling Loss on Vehicle Fuel Consumption. Tire Science and Technology, Vol. 22, No. 3, pp. 149-161.

[7]. Schuring, D. J., and S. Futamura. 1990. Rolling Loss of Pneumatic Highway Tires in the Eighties. Rubber Chemistry and Technology, Vol. 62, No. 3, pp. 315-367.

[8]. NRC. 2002. Effectiveness and Impact of Corporate Average Fuel Economy (CAFE) Standards.

[9]. P.Zappoli, Dept. of Science and Industrial Research, 1991. Conversion of Internal Combustion Engines to Alcohol Fuels. A Lecture Report in Shenyang Agricultural University, China.

[10]. The Brazilian Ethanol Producer's special Committee, Ethanol: The Renewable and Ecological State Solution, Sao paulo, June 1985.

[11]. Lu Nan, 1992. Technique of Alcohol Production from Sweet Sorghum Stalks, Research and Development of Biomass Energy Technology In China.

[12]. Harlan W. Van Gerpen, Robert L. May field, Dyna-cart-A Programmable Drawbar Dynamometer for Evaluating Tractor Performance, ASAE Paper No. 821056, 1982.

[13]. I. W. Grevis-James, D. R. DeVoe, P. D. Bloome, D.G. Batchelder and B. W. Lambert, MicrocomputerBased Data Acquisition for Tractors, TRANSACTIONS of the ASAE-1983.

[14]. Shobha S. Borhade - Replacement of furnace oil and Light diesel oil (LDO) by cashew nut shell oil. Standard test method for sulfated Ash from Lubricating oils and additives D 874:163 (1996).

[15]. Standard test method for sulfur in Petroleum products 107/ 86 : D $1796-2010$. 